\title{
Mental Problems Accompanying Diabetes and Management of Diabetes
}

\author{
Diyabete Eşlik Eden Ruhsal Sorunlar ve Diyabet Yönetimi \\ Ilyas ÇAPO $\breve{G L} U^{*}$, Arzu YILDIRIM², Rabia HACIHASANOĞLU AŞILAR ${ }^{3}$, Ali ÇAYKÖYL $\ddot{U}^{4}$
}

\begin{abstract}
Diabetes is a major public health issue that affects the nations of our time to a large extent and is described as a non-communicable epidemic. Mental factors are important in sustaining a good glycemic control. Comorbid mental problems and particularly depression have a negative impact on self-care and are associated with poor glycemic outcomes and increased risk of complications. For this reason, health professionals should not overlook mental problems in the management of diabetes and be aware of the risk of suicide especially in depressive patients. The fundamental components of self-management of diabetes are education, diet, follow-up, life style, and compliance with treatment. Perseverance with self-management methods requires high motivation and most of the patients and particularly those experiencing mental and social problems may find the self-management strategies challenging. This paper deals with diabetes, management of diabetes, the nature of mental disorders in diabetes and the effect of diabetes management on patient outcomes. It also stresses the importance of a cooperative and multidisciplinary teamwork that enable the patient to assume an active role in self-care through education and support in the self-management of diabetes within a framework of practicable strategies and individual-focused holistic approach.
\end{abstract}

Key words: Diabetes, mental problems, diabetes management, health professionals

\section{ÖZET}

Diyabet, günümüz toplumlarını önemli düzeyde etkileyen bir toplum sağlığı sorunu olup bulaşıcı olmayan salgın bir hastalık olarak belirtilmektedir. Ruhsal etkenler, iyi glisemik kontrolün sürdürülmesinde önemlidir. Başta depresyon olmak üzere ona eşlik eden ruhsal sorunlar özbakımda olumsuz bir etkiye sahip olup bu durum kötü glisemik sonuçlar ve artan komplikasyon riski ile ilişkilidir. Bu nedenle sağlık profesyonelleri diyabet yönetiminde ruhsal sorunları göz ardı etmemeli, özellikle depresif hastalarda özkıyım riskinin farkında olmalıdırlar. Diyabet öz yönetiminin temel unsurları: eğitim, diyet, izlem, yaşam biçimi ve tedaviye uyumdur. Öz yönetim önlemlerinin sürdürülmesi yüksek motivasyon gerektirmekle birlikte hastaların çoğu, özellikle ruhsal ve toplumsal sorunlar yaşayanlar öz yönetim stratejilerini zorlayıcı bulabilmektedir. Bu yazıda: diyabet, diyabet yönetimi, diyabette ruhsal bozuklukların doğası ve diyabet yönetiminin hasta sonuçlarına etkisi ele alınmaktadır. Ayrıca uygulanabilir stratejiler ve birey odaklı bütüncül bir yaklaşım içerisinde diyabet öz yönetim eğitimi ve desteği ile hastanın kendi bakımında aktif rol üstlenmesini sağlayan işbirlikçi ve çok disiplinli ekip çalışmasının önemi vurgulanmaktadır.

Anahtar kelimeler: Diyabet, ruhsal sorunlar, diyabet yönetimi, sağlık profesyonelleri

Received Date / Geliș Tarihi: 20.04.2018 Accepted Date / Kabul Tarihi: 02.07.2018

${ }^{1}$ Atatürk Üniversitesi $\quad$ Tip Fakültesi/ İç Hastalıkları $\quad$ ABD/Endokrinoloji,

${ }^{2}$ Erzincan Binali Yıldırım Üniversitesi Sağlık Bilimleri Fakültesi/Ruh Sağlığ ve Psikiyatri Hemşireliği ABD, Erzincan/Türkiye

${ }^{3}$ Erzincan Binali Yıldırım Üniversitesi Sağlık Bilimleri Fakültesi/Halk Sağlığı Hemşireliği ABD, Erzincan/Türkiye

${ }^{4}$ Ankara Yıldırım Beyazıt Üniversitesi Tıp Fakültesi/Ruh Sağlığı ve Hastalıkları ABD, Ankara/Türkiye

*Address for Correspondence / Yazışma Adresi: Arzu Yıldırım, Erzincan Binali Yıldırım Üniversitesi Sağlık Bilimleri Fakültesi/Ruh Sağlığı ve Psikiyatri Hemşireliği ABD, Erzincan/TürkiyeE-Mail: yildirimarzu25@ hotmail.com

Çapoğlu İ, Yıldırım A, Hacıhasanoğlu Aşılar R, Çayköylü A. Diyabete Eşlik Eden Ruhsal Sorunlar ve Diyabet Yönetimi. TJFMPC, 2019 ; 13

(1): 67-74-- DOI: 10.21763/tjfmpc.415456-- 


\section{GíRiș}

Diabetes mellitus (DM) insülin salınımı, insülin etkisi veya her ikisindeki eksiklikten kaynaklanan ${ }^{1}$ kontrolsüz kan şekeri yükselmesi ile belirli ${ }^{2}$, glisemik kontrolün ötesinde çok etkenli risk azaltma stratejileri ile birlikte sürekli tıbbi bakım gerektiren karmaşık ve kronik metabolik bir hastalıktır. ${ }^{3}$ Sıklı̆̆ 1 ve yaygınlığı artan, glikotoksisite etkileri nedeniyle ciddi komplikasyonlara neden olabilen $\mathrm{DM}^{2}$, dünyada ulusal sağlık bakım sistemine ciddi bir ekonomik yük getiren morbidite ve mortalitenin önemli nedenlerinden biridir. Ayrıca hastalar tarafından da bildirildiği gibi yaşam kalitesinin azalmasına yol açan fiziksel ve psikolojik engelliliğin klinik açıdan önemli bir kaynağıdır ${ }^{1}$. Uluslararası Diyabet Federasyonu ${ }^{4}$ 7. Diyabet Atlası tahminlerine göre küresel yaygınlık 2015'te \%8.8 (415 milyon), 2040 'ta \%10.4 (642 milyon) olup Türkiye, Avrupa ülkeleri arasinda \%14.6 (7 milyondan fazla) ile diyabet oranının en yüksek olduğu ülkedir. ${ }^{5}$ Toplumsal ve küresel bir sorun haline gelen DM'un belirtilen epidemik oranlara ulaşması, bu sorunun erken dönemde ele alınmasını ve etkili yönetimini zorunlu kılmaktadır.

Bireyin çok sayıda günlük öz yönetim kararları almasını ve karmaşık bakım faaliyetlerini gerçekleştirmesini gerektiren ${ }^{6}$ diyabet yönetiminde, iyilik halini ve yaşam kalitesini sürdürme, risk etkenlerini kontrol altına alma, hastalık belirtilerini yönetme ve komplikasyonların slklığını azaltma önemli hedeflerdir. ${ }^{l}$ Klinik uygulama rehberleri, toplum sağlığını iyileştirmenin anahtarı olmakla birlikte en iyi sonuca ulaşmada diyabet bakımının her hasta için ayrı ayrı yapılması gerekmektedir. Tedavi, kanta dayall rehberlere temellenmeli ve prognoza ve ek hastaliklara dayalı olarak hastalarla iș birliği içerisinde yapılmalıdır. ${ }^{7}$

En uygun diyabet yönetimi; organize, sistematik bir yaklaşımı ve hasta odaklı yüksek kaliteli bakımın ön planda olduğu bir ortamda eş güdüm içerisinde çalışan sağlık ekibinin katılımını gerektirir. ${ }^{8}$ Diyabet hastaları için daha etkili sağlık bakımı sunum sistemleri tasarlama ve uygulamasinda sağlık bakım profesyonellerine yardımcı olacak hedefler:

1- En uygun destekleyici ve ekip davranışı: Tedaviye hastayı da dahil eden bakım ekibi, önerilen metabolik hedeflere ulaşamayan hastalar için zamanında ve uygun yaşam biçimini ve/veya ilaç tedavisini güçlendirmeye öncelik vermelidir.

2- Hasta öz yönetimini destekleme: Başarılı diyabet bakımı, davranış değişimi çabalarını destekleyen sistematik yaklaşımı gerektirir. Bu yaklaşımlar:

Sağlıklı yaşam biçimi seçenekleri (sağlıklı beslenme, fiziksel aktivite, tütün kullanmama, kilo yönetimi ve stresle etkili baş etme stratejileri).

Hastalık öz yönetimi (ilaç kullanma ve yönetimi, klinik açıdan uygun olması durumunda glukoz ve kan basıncinı kendi kendine izlem).

Diyabet komplikasyonlarını önleme (kendi kendine ayak sağlığı izlemi, göz ve böbrek komplikasyonları izlemine aktif katılım ve bağışıklama).

Öz yönetim sorunlarını belirleme ve bireyin belirlediği davranışsal hedefleri içeren sorunlara çözüm stratejileri geliştirme

3-Bakım sistemini değiştirme: En başarılı bakım sistemi özelliği; kurumsal öncelikli, yüksek kaliteli bakım sağlamaktır. Diyabet bakım kalitesini arttıran değişiklikler, kanıta dayalı rehber doğrultusunda bakım sağlamayı kapsamalıdır. ${ }^{7-10}$
Toplumun sağlık durumunu iyileştirme çabalarl, sistem ve hasta düzeyinde yaklaşımların birleşimini gerektirir. Diyabet yönetiminde sistem düzeyinde ele alınması gereken sağlikta eşitsizliklerin çeşitli nedenleri olup rrkçılık, ayrımcılık, sosyoekonomik durum, sağlık bakımına yetersiz erişim, eğitim ve sağlık sigortasının olmaması gibi toplumsal konuları içermektedir. ${ }^{11,12}$ Obezite, gıda güvensizliği, fiziksel hareketsizlik ve sigara içmenin diyabetli hastaların sağlığı üzerinde çok büyük etkisi olduğundan bu sorunların toplumsal faktörleri irdelenmeli ve değiştirilmelidir. ${ }^{7}$ Gıda güvensizliği, daha pahalı ve besleyici yiyecekleri satın almak yerine obeziteye yol açabilecek daha ucuz, enerji ve karbonhidrattan yoğun işlenmiş yiyecekler almayı kapsamaktadır. ${ }^{13}$ Diyetin niteliksel bileșenlerinin kilo alımı ile ilişkilendirildiği ve sağlıksız beslenenlerde Tip 2 DM (T2DM), riskinin arttığ1 bilinmektedir. Kronik hastalığı olmayan 120.877 erkek ve kadını içeren üç ayrı kohortun dört yıl aralıklarla değerlendirildiği prospektif bir çalışmada meyve, sebze, tahıl, sert kabuklu yiyecekler ve yoğurt tüketiminin kilo alımı ile negatif; patates cipsi, patates, şekerle tatlandırılmış meşrubat, işlenmemiş kırmızı et ve işlenmiş et tüketiminde artışın kilo alımı ile pozitif yönde ilişkili olduğu belirlenmiştir. ${ }^{14}$

Sağlıkta eşitsizliklerin ortadan kaldırılması, sistem düzeyinde girişimler kadar; bireyselleştirilmiş, hasta merkezli ve kültürel olarak uygun stratejiler de gerektirir. Farklı toplumlar için geliştirilen ve kültür, dil, din ve ekonomi gibi özellikler yönünden bütünleştiren, yapılandırılmış müdahaleler hasta sonuçlarını olumlu yönde etkilemektedir. ${ }^{11,12}$

Diyabet nöropati, makülopati, böbrek yetmezliği ve ampütasyon gibi glikotoksisitenin sonuçlarını oluşturan ciddi komplikasyonlar ile ilişkili olduğundan glisemik kontrol önemlidir. ${ }^{2} \mathrm{Bu}$ nedenle hasta, aile ve sağllk ekibi yaşam biçiminin yönetimini içeren yönetim planını birlikte şekillendirmelidir. Yönetim planında hastanın yaşı, bilişsel yetenekleri, okul/çalışma programı ve koşulları, sağlık inançları, destek sistemleri, yeme düzeni, fiziksel aktivitesi, toplumsal ve ekonomik durumu, kültürel etkenleri, okur-yazarlık ve aritmetik becerileri, diyabet komplikasyonları, eşlik eden hastalıklar, sağlık öncelikleri, diğer tıbbi durumlar, bakım tercihleri ve yaşam beklentisi göz önünde bulundurulmalıdır. ${ }^{15}$ Diyabet bakımının bileşenleri şekilde gösterilmiştir. ${ }^{16}$

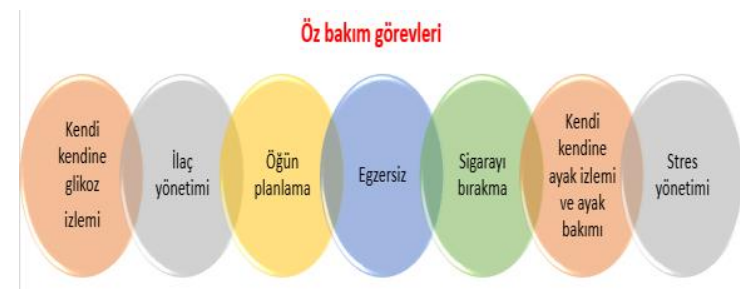

Testler/yıllık değerlendirmeler

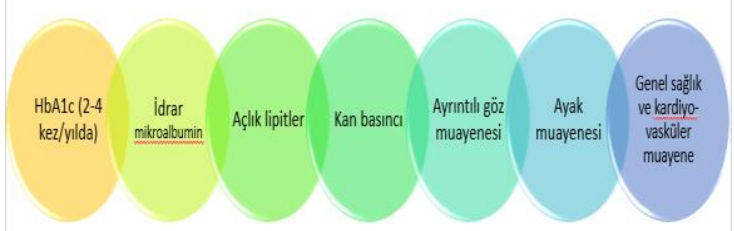

Şekil: Diyabet bakımının bileşenleri 
Hastaların tıbbi öyküsü, fizik muayenesi ve laboratuvar testlerine ek olarak, diyabet özyönetim davranışları, beslenme ve ruhsal toplumsal sağlıkları değerlendirilmelidir. ${ }^{15}$ Ayrıca hastaların uyku düzeni ve süresi de değerlendirilmelidir. Yakın zamanda yapılan sistematik derleme ve meta-analiz çalışmasında kötü uyku kalitesinin ve normal uyku süresine göre kısa ve uzun süreli uykunun T2DM'u olanlarda daha yüksek düzey glikozillenmiş hemoglobin (HbAlc) ile ilişkili olduğu gösterilmiştir. ${ }^{17}$

\section{Diyabete Eşlik Eden Ruhsal Bozukluklar}

Ciddi ruhsal bozukluğu özellikle depresyonu olan hastalar ile diyabeti olan hastalarda karş111klı duyarlılık ve yüksek düzeyde eş hastalanma görülmektedir. ${ }^{18}$ Diyabeti olan bireylerde genel nüfusa göre özellikle majör depresif bozukluk (MDB), yaygın anksiyete bozukluğu (YAB) ve yeme bozukluğu (YB) gibi ruhsal bozukluklar daha yaygin olup MDB, iki uçlu duygudurum bozukluğu ve şizofreni gibi ciddi ruhsal bozukluğu olan bireyler genel nüfusa göre daha fazla diyabet gelişme riski altındadır. ${ }^{18,19}$

Bilişsel zayıflama/Demans: T2DM, bilişsel zayıflama ve demans arasında bağlantı olduğuna ilişkin birçok gözlemsel araştırma kanıtı belirtilmektedir. T2DM ile birlikte hipergliseminin derecesi ve süresi demans ile; daha hızlı bilişsel zayıfama ise HbA1c artışı ve uzayan diyabet süresi ile ilişkilidir. ${ }^{20}$ Demans etiyolojisinde diyabetin potansiyel olarak değiştirilebilen en büyük risk etkenlerinden biri olduğu, bunların arasında en başta klasik vasküler risk etkenlerinin bulunduğu ileri sürülmektedir. ${ }^{21}$ Prospektif gözlemsel çalışmaların meta analizinde diyabetli hastaların, diyabeti olmayanlara göre her türlü demans riskinde \%73, Alzheimer tipi demans riskinde $\% 56$ ve vasküler demans riskinde $\% 127$ artıș bildirilmektedir. $^{22}$ Danimarka'da ulusal nüfusa dayalı yapılan kohort çalışmasında, depresyonun DM'a eşlik etmesinin özellikle 65 yaşından küçük bireylerde demans gelişiminde bağımsız olarak yüksek risk gösterdiği belirlenmiştir. ${ }^{23}$ DM'li hastaların beyninde biyolojik değişiklikler olduğu belirtilmektedir. Duygulanım ve bilişten sorumlu beyin bölgelerindeki yapısal, işlevsel ve nörokimyasal değişiklikler Tip 1 DM (T1DM) ve T2DM'ta depresyon riskini arttırabilmektedir. Hayvan modelleri; hipergliseminin hipokampal bütünlüğü ve nörogenezi olumsuz etkilediğini, nöroplastisiteyi azalttığını ve duygudurum bozukluklarına yol açtığını göstermektedir. ${ }^{24}$

Depresyon ve Özklyım: Diyabet hastalarında klinik olarak ilişkili depresif belirtilerin yaygınlığ $1 \% 30$, MDB yaygınlığı ise yaklaşık \%10 dolayındadır. ${ }^{18}$ Depresyon T2DM'a bağlı ortaya çıkabileceği gibi T2DM için bir risk etkeni oluşturabilmektedir. Depresyonu olan bireylerde T2DM gelişme riski ise $\% 60$ artmaktadır. Hipofizhipotalamus-böbrek üstü bezi ekseninin düzenlenmesinde kronik bozukluğa bağlı yüksek kortizol düzeyi, insülin duyarsızlığında azalma ve bağışıklık sisteminde kronik inflamatuar süreçlere yol açan etkinlik artışı her iki hastalığın ortaya çıkmasına zemin hazırlayan ortak nöroendokrin düzenekler olarak görülmektedir. ${ }^{25,26}$ Diyabetli hastalarla yapılan bir çalışmada hastaların yaklaşık \%84'ünde depresyon eş tanısı ve kadınlarda depresyon ve anksiyete yaygınlığı ve ciddiyet düzeyinin daha yüksek olduğu rapor edilmiștir. Ayrıca cinsel sorunların genellikle erkeklerde, bedensel belirtilerin ise kadınlarda daha yaygın olduğu belirlenmiştir. ${ }^{27}$ Depresif hastalarda diyabet gelişiminin olası etkenleri ise insülin direncine yol açan fiziksel hareketsizlik, obezite ve kortizol salınımı ile kronik hipotalamik pituiter adrenal aktivasyona yol açan ruhsal zorlanmadır. Diyabete eşlik eden depresyon, yaşam kalitesini ciddi düzeyde olumsuz etkiler ve daha fazla hasarla sonuçlanır. Depresyonla birlikte görülen letarji özbakım motivasyonunu düşürerek fiziksel ve ruhsal zindelikte ve ilaca uyumda azalma ve sağlık hizmetlerinin daha sik kullanılması ile sonuçlanır. ${ }^{18}$ Depreyon nedeni ile özbakımda kötüleşme ayrica randevulara gelmemeye, düzensiz yemeye, kendine zarar vermek için insülin kullanmaya, yetersiz glisemik kontrole ve komplikasyon riskinde artmaya yol açarak klinik sonuçları kötüleștirir ve kardiyovasküler mortaliteyi arttırır. ${ }^{28,29}$ Bangladeş'te 417 T2DM hastası ile yapılan bir çalışmada hastaların \%34'ünde depresif belirti saptanmış ve kötü glisemik kontrol ve eşlik eden hastalık sayısı ile depresyon arasında güçlü bir ilişki olduğu gösterilmiştir. ${ }^{30}$ Depresyonun tanı ölçütleri arasında yer alan uykusuzluk, iştah ve kilo kaybı, halsizlik gibi bedensel hastalıklarda da sik görülen belirtilerin bulunması bedensel hastalıklarda depresyon tanısını güçleştirmektedir. Bedensel hastalık olup olmaması dikkate alınmadan aynı tanı ölçütleri kullanılarak depresyon tanısı konulmalıdır. Diyabeti olan bireyde depresyon varsa ilk seçilecek ilaç bir seçici serotonin geri alım önleyicisi (SSGÖ) olmalıdır ancak uzun süreli SSGÖ kullanımının diyabet riskini arttırdığına ilişkin verilerin bulunduğu unutulmamalıdır. ${ }^{26}$ Literatür analizi DM ciddiyetinin özkıyım riskini arttırabileceğini göstermektedir. Özkıyım riski biyolojik, ruhsal, toplumsal ve kültürel etkenleri içeren çok yönlü bir sorundur. Kuzey Finlandiya'da 2489 özkıyımda bulunan birey ile nüfusa dayalı olarak DM hastalarında özkıyım özelliklerini değerlendiren bir çalışma yapılmışıı. Özkıyımda bulunanların \%3.1'inde (T1DM $=\% 34.6$ ve $\mathrm{T} 2 \mathrm{DM}=\%$ 65.4) $\mathrm{DM}$ olduğu, T2DM hastalarının \% 24'ünün özkıyım sonucu öldüğünde alkolün etkisi altında olduğu; bu durumun T1DM hastalarında \% 44.4, DM'u olmayanlarda ise \% 46.6 olduğu belirlenmiştir. Ayrıca T2DM veya DM'u olmayan hastalarla karşılaştırıldığında T1DM hastalarında depresyonun daha yaygın olduğu ve özkıyım yöntemi olarak kendilerini zehirledikleri, kendini zehirleme vakalarının yarısında insülin kullanıldığı, T2DM'u olanlarda ise bu durumun \%13 düzeyinde olduğu belirlenmiştir. $^{31}$ Yapılan 17 araştırmanın sistematik inceleme ve meta-analiz çalışmasında DM'nin, özellikle depresif belirtileri olan hastalarda, özkıyım davranışları ve düşüncesinde belirgin bir artış ile önemli derecede ilişkili olduğu, insülin tedavisi, uzun süreli $\mathrm{DM}$ ve yetersiz glisemik kontrolün T1DM ve T2DM 'de özkıyım düşüncesinde risk etkenleri olarak tanımlandığ 1 gösterilmiștir. ${ }^{1}$ Avustralya'da T1DM ve T2DM'u olan 3338 yetişkin birey ile yapılan toplum temelli bir çalışmada da özkıyım düşüncesinin $\% 14$ olduğu bulunmuştur. Bunun yanı sıra insülin kullanan T2DM hastalarının daha sık depresif belirti bildirdiği ve insülin kullanmayanlara göre özkıyım düşüncesinin daha fazla olduğu ve diyabete özgü yüksek sıkıntının özkıyım düşüncesini önemli düzeyde arttırdığı bildirilmiştir. ${ }^{32}$ Ülkemizde beş vakanın değerlendirildiği bir çalışmada ise laktat birikimine yol açan oral anti-hiperglisemik ilaç 
olan yüksek doz metformin ile özkıyım girişiminde bulunulduğu belirlenmiştir. ${ }^{33}$

Anksiyete bozuklukları: Bedensel hastalığı olan bireyler; hastalığı ile ilişkili bilinmezler, yapılacak inceleme ve sağaltım uygulamalarının korkusu, acı ve ölüm çağrıştıran hastane ortamı gibi etkenler ile kendilerini iç ve diş tehditlerin altında hisseder. Bu tehditler ile baş edilemediğinde çok şiddetli duygusal tepkiler ortaya çıkabilmektedir. Ayrıca anksiyete, bedensel hastalığın kendi belirtisi de olabilmektedir. Bu nedenle bedensel hastalığı ve anksiyetesi olan hastanın değerlendirilmesi güçtür. ${ }^{26}$ Diyabetli bireylerin \%14'ünde YAB, \%40'1nda bazı anksiyete belirtileri görülmüş ve anksiyete belirtileri yetersiz glisemik kontrolle ilişkilendirilmiş̧ir. ${ }^{2}$ Katar'da 889 DM hastası ile yapılan çalışmada hastaların sağlıklı kontrollere göre sırası ile önemli düzeyde depresyon (\%13.6; \%5.9), anksiyete (\%35.3; \%16.3), stres (\%23.4; \%10) deneyimlediği; depresyonda önemli öngörücülerin sistolik kan basınc1 (SKB), diyabet süresi ve obezite; anksiyetede ise SKB, diyastolik kan basınc1 (DKB) ve fiziksel aktivite olduğu ve anksiyetenin depresyon ve stresten daha fazla sıklıkla görüldüğü tespit edilmiştir. ${ }^{34}$ Türkiye'de 400 T2DM hastası ile yapılan bir çalışmada ise hastaların \%21.8'inde anksiyete, \%42'sinde depresyon belirtileri saptanmıştır. ${ }^{35}$ Anksiyete bozuklukları, özellikle iğne fobisi ve buna bağlı olarak insülin ve kan glikozu izleminden kaçınma ${ }^{2}$, diyabet komplikasyonlarına ilişkin anksiyete nedeni ile kan glikozunu düşük düzeyde tutma ve hipoglisemi atak riski, obsesif kompulsif bozuklukta kan glikozunu aşırı düzeyde kontrol etme gibi durumlar öz yönetimi olumsuz yönde etkileyebilmektedir. ${ }^{15,28,29}$

Yeme bozukluklart: Sistematik inceleme ve meta-analiz çalışmasında T1DM hastalarında bozulmuş yeme davranışı $(\% 51.8)$ ve YB (\%6.4) sorunlarının genel nüfusa kıyasla yaygın olduğu gösterilmiştir. ${ }^{36}$ T1DM'ta kilo vermek için glikozüriye neden olan insülin ihmali, T2DM'u olan hastalarda ise tıkanırcasına yeme bozukluğu (kontrol kaybına eşlik eden aşırı yiyecek alımı) sık görülmektedir. ${ }^{15,37}$ Kilo kontrolü için insülin k1sitlaması diyabet yönetimini tehlikeye sokarak hiperglisemi, mikrovasküler komplikasyon risk artışı, diyabetik ketoasidoz nedeni ile tekrarlayan hastane yatışları, erken ölüm ve aile zorlanmalarına yol açabilmektedir. ${ }^{2,15}$ Depresif belirtilerle birlikte T2DM'u olan bireylerde ise gece yeme sendromunun görüldüğg̈ belirtilmiştir. Akşam yemeğinden sonra günlük kalorinin \% 25'inden fazlasını alma ve ortalama haftada en az üç defa gece yemek yeme için uyanma olarak nitelendirilen bu durum kilo alma, yetersiz glisemik kontrol ve diyabetik komplikasyon sayısında artıș ile sonuçlanır. ${ }^{18}$ İnsülin ile tedavi edilen T2DM'lu bireylerde kasitlı ihmal de sıkça bildirilmektedir. Bu hastalarda glukagon benzeri peptit 1 agonistleri gibi yardımcı ilaçlar yalnızca glisemik hedefleri karşılamakla kalmayıp aynı zamanda açlık ve besin alımını düzenleyerek kontrol edilemeyen açlık ve bulimik belirtileri azaltma olasılığına sahiptir. ${ }^{15,28}$

Uyum bozukluklart: Ruhsal toplumsal zorlanmanın sonucu olarak sıkıntı düzeyinin beklenenden yüksek olması ve bireyin baş etme veya iş görme yeteneğini etkilemesi durumunda uyum bozukluğu tanısı konulabilir. $\mathrm{Bu}$ durum öz yönetimde kötüleşme, davranış bozuklukları, depresyon ve/veya anksiyete belirtileri ile kendini gösterir. Tanı konulduktan sonra diyabetle ilişkili yüksek düzeyde sıkıntı, uyum bozukluğu başlangıcını tetikleyebilmektedir. ${ }^{29}$ Bir diyabet merkezinden liyezon psikiyatrisi diyabet kliniğine yönlendirilen bireylerde tedaviyi gerektirecek ruhsal durumların belirlenmesi amacı ile yapılan ileriye dönük bir çalışmada, en yaygın psikiyatrik tanının uyum bozukluğu (\%28.6) olduğu rapor edilmiştir. ${ }^{38}$

Şizofreni: Şizofreni ve diğer psikotik bozukluklar, diyabet için bağımsız risk etkeni olabilmekte ve psikotik bozukluğu olan bireyler incinebilir grubu göstermektedir. Şizofreni hastalarında, T2DM yaygınlığı iki-üç kat artmış olup T1DM daha az yaygınlıktadır. ${ }^{18}$ Şizofreni ve T2DM arasındaki eş hastalığa katkıda bulunan etkenler: fenotip hipotezi, otonomik hiperaktivite, potansiyel hücresel ve genetik bağlantılar gibi çoklu ve karmaşık mekanizmalar olarak belirtilmektedir. ${ }^{16}$ Ayrıca meyve ve sebzeden yoksun, doymuş yağlar ve rafine şekerler yönünden zengin diyet, D vitamini eksikliği, sigara, hareketsiz yaşam, gelir, konut ve gıda güvensizliği gibi sağlığın sosyal belirleyicileri ve antipsikotik kullanımı olarak sıralanmaktadır. ${ }^{39}$ Diyabet gelişim sürecini bilmek, hastalığın yönetiminde önemlidir. İnsülin direnci T2DM öncüsü olup glikozu kandan hücrelere taşımak için insülin gerekmektedir. Kilo alma, özellikle de abdominal şişmanlık (yağlanma), insülin direncinin başlıca etkenidir. Vücut glikoz homeostazını korumak için daha fazla insülin üretir. Hiperinsülinemi ise T2DM gelişimi için önemli bir risk belirleyicisi olan metabolik sendrom nedenidir. Diyabet genellikle yıllar sonra pankreasin insülin direncini dengeleyemediği durumda gelişir. ${ }^{16,39}$ Ülkemizde 111 şizofreni hastası ile yapılan bir çalışmada da hastaların \%27'sinde metabolik sendrom saptanmıştır. ${ }^{40}$

Metabolik durumlarl tedavi etmek, psikiyatrik uygulamaların dişında kalmakla birlikte şizofreni hastalart ile ilgilenen klinisyenler diyabet izleminde en iyi konumda oduklarından antipsikotik tedavi süresince temel metabolik parametreleri izlemeli ve tıbbi girișimleri desteklemelidir. ${ }^{39}$ Hastaya diyabet tanisı konulduktan sonra diyabet ve ruh sağlığı tedavi ekibi olumlu ilişkiler geliştirmeli ve diyabet bakımı için hasta ile birlikte çalışılmalıdır. Girişimler, metformin gibi farmakolojik tedavinin yanı sira kilo verme, fiziksel aktiveteyi arttırma, diyet ve sigarayı bırakma gibi yaşam biçimine odaklanmalidır. ${ }^{16}$

Psikotik bozuklukların yönetiminde anahtar bir bileşen olan antipsikotikler, direkt olarak insülin direncini arttırarak veya insülin salınımını azaltarak ya da dolaylı olarak vücut ağırlığını arttırarak diyabet gelişme riskini artırabilmektedir. Amisülpirid, aripiprazol ve ziprasidon dışında tüm antipsikotikler uzun süreli kullanım ile kilo alımına neden olmaktadır. Antipsikotikler, pankreasın $\beta$ hücreleri tarafından insülin salınımı için önemli bazı çoklu reseptörlerle etkileşime girer. ${ }^{39}$ Atipik antipsikotiklerde hiperglisemi insidansı tipik antipsikotiklere göre üç kat daha fazla olup bu artan riske çoğunlukla olanzapin ve klozapin neden olmaktadır. ${ }^{2}$ Var olan diyabet klozapin de dahil olmak üzere antipsikotik tedaviye kontrendikasyon oluşturmamalıdır. Birçok psikiyatrist için yüksek/orta düzey metabolik yatkınlığı olan antipsikotiklerden düşük metabolik yatkınlığı olana geçiş kararı zordur. İlacın metabolik görünümü, bir antipsikotik seçiminde kilit öneme sahip olmakla birlikte bireyin sağlığını daha kapsamlı göz önünde tutma yönünden dengelenmelidir. İnatçı psikoz durumunda en etkin ilaç olan klozapinin, metabolik yan etki oranı çok 
yüksektir. ${ }^{41,42}$ Ancak şizofreni hastalarında antipsikotik ilaç seçerken ruhsal bozukluğun etkili tedavisinin bireyin fiziksel ve ruhsal sağlığını yönetme yeteneğini iyileştirdiği düşüncesi ile klozapin kullananların daha uzun süre yaşadığı kanıtı da göz ardı edilmemelidir., ${ }^{2,42}$ Şizofrenide antipsikotikler ile birlikte kilo vermede metformin ve lipid profillerini iyileştirerek metabolik sağllğ geliştirmek için klozapine ek olarak aripiprazolün kullanımı gibi farmakolojik stratejiler, bu hastalarda kardiyovasküler risk etkenlerini gidermede etkili olabilmektedir. ${ }^{18}$

Şizofreni hastalarinda yoksunluk belirtileri ile birlikte yürütücü işlevsellik ve çalışma belleğinde bozulma, motivasyon eksikliği, toplumsal ve ekonomik olumsuzluklar nedeni ile özbakımın zorlaştı̆̆ı göz önünde bulundurulmalıdir. ${ }^{39}$

İki uçlu duygudurum bozukluğu: İki uçlu duygudurum bozukluğu olan hastalarda genel nüfusun iki katı metabolik sendrom, üç katı diyabet tahmin edilen yaygınlı oranları bildirilmektedir. ${ }^{18}$

\section{Diyabette Belirli Ruhsal Sorunlar}

Diyabet; glisemik kontrol, komplikasyonların gelişimi, fiziksel engellilik ve ölüm oranına doğrudan etki edebilecek belirli ruhsal sorunlarla ilişkilendirilir. ${ }^{37}$ Diyabetin bazı komplikasyonları özellikle de cinsel sorunlar, aynı zamanda belirli ruhsal güçlükleri de beraberinde getirebilmektedir. ${ }^{27}$

Diyabette psikiyatrik değerlendirme göstergeleri:

-Depresif duygudurum belirtisi,

-Düşük BKİ: Yeme bozukluğuna işaret edebilir,

-Insülin tedavisine başlamada isteksizlik: İğne fobisi veya insülin korkusunu gösterebilir,

- Sürekli yetersiz glisemik kontrol,

- Yineleyen hastane başvuruları (örneğin diyabetik ketoasidoz, tekrarlayan ciddi hipoglisemi),

- Yetişkinlere yönelik hizmetlerde karşıllaşılan zorluklar olarak belirtilmektedir. ${ }^{37}$

Tanının kabulü, inkâr ve belirsizlik: Yeni bir diyabet tanısı bunaltıcı olup bireyler özellikle uzun vadeli sekellerden kaçınılması için sürekli öz yönetim gerektiren bir hastalığı kabullenmede güçlük yaşamaktadır. $\mathrm{Bu}$ durum depresif bir tepkiden inkâra ve kaçınmaya kadar yetersiz glisemik kontrol ile sonuçlanabilen çeşitli yanıtlar içerebilir. ${ }^{2,43}$ Tanı ile başa çıkma ve günlük hayata öz yönetimi dahil etme sürecine başlamak için bir diyabet eğitimcisi ya da sağlık ekibi üyesi; hasta bireyle ve aile üyeleri ile acil sorulara cevap vermek, ilk anksiyeteyi gidermek, destek sağlamak ve gerekli kaynaklara yönlendirmek için yakından çalışmalıdır. Eğitimciler, birey ve aile üyelerinin devam eden eğitime ve desteğe dahil edilmesinin önemini ve tedavi değişikliklerinin hastanın başarısız olduğu anlamına gelmediğini vurgulamalıdır. ${ }^{6}$

Hipoglisemi korkusu: Hipoglisemi ile ilişkili ciddi fiziksel risklere ilaveten hipoglisemik atak hoş olmayan öznel bir deneyimdir. ${ }^{37}$ Hipoglisemik ataklardan dolayı işini kaybetme, toplumsal yalıtım, otonomide yetersizlik $^{29}$, üçüncü kişi yardımı, bilinç kaybı ve hatta hastaneye kabulü gerektirecek kadar ağır olabilen bu deneyimi tekrar yaşamamak için anksiyete yaşayan birey, kan glikozunu önerilenden daha yüksek (özellikle gece) düzeyde tutar ve bunun sonucunda glisemik kontrol bozulur. $^{37}$ Diyabeti olan bireylerin karşılanmamış gereksinimlerini belirlemek için yapılan küresel çalışma grubu DAWN2 sonuçlarına göre hastaların $(\% 56)$ ve aile üyelerinin (\%61) yarısından fazlası hipoglisemi konusunda çok endişelendiklerini bildirmişlerdir. ${ }^{44}$

Komplikasyon korkusu: Diyabetin olas1 komplikasyonları, tanı konulan hastalara açıklanmaktadır. Hastaların çoğu, bu bilgiyi adım adım alır ancak az sayıda hasta bu durumları geliştirme korkusu yaşar. ${ }^{28,44}$ Çabalarına rağmen yüksek glikoz düzeyi olan bazı bireyler, hangi adımları atarsa atsın hastalığını tam olarak kontrol edemez ve bu durumda komplikasyonların kaçınılmaz olduğunu düşünürler. Birey diyabet kontrolü konusunda cesaretinin kırılmış olduğunu hisseder ve bu başarısızlık duygusundan kaçınmak için gerekli özbakım faaliyetlerini yapmaz, bu durumda diyabet komplikasyonları gelişme riski artabilir. ${ }^{37,44}$

Uyum güçlüğ̈̈: Diyabetli bireylerin çoğu, hastalığını iyi yönetmek için nelere gereksinim duyduklarını bilir ancak bazıları en iyi diyabet kontrolü için gerekli özbakım rejimine tam olarak uyumu güç bulur. Bu durum bireyin dikkatini dağıtan ruhsal bozukluk ve toplumsal sorunlar da dahil olmak üzere çok çeşitli nedenlerden kaynaklanabilmektedir. Öz yönetim gereksinimlerini yoğun bir yaşam biçimine dahil etmek zor olabilmektedir. Özbakım faaliyetlerinin yapılması için birey bunları önemsemeli ve öncelik vermelidir. ${ }^{2,43,44}$

Diyabet sıkıntısı: Sürekli izlem ve tedavi gerektiren umutsuzluk ve koşullara bağlı duygusal karmaşayı ve komplikasyonlarla ilişskili sürekli anksiyeteyi, kişisel ve mesleki ilişkilerdeki potansiyel bozulmayı tanımlar. Diyabet sıkıntısı, majör depresif bozukluk ve depresif belirtiler arasında ayrım yapmak önemlidir çünkü bu ruhsal deneyimlerin üçü de birbirinden farklıdır ve olumsuz diyabet sonuçları ile en güçlü ilişkili olan diyabet sıkıntısıdır. ${ }^{18,28}$ Norveç'te T1DM hastaları ile yapılan bir çalışmada da diyabete özgü duygusal sıkıntının glisemik kontrol ile ilişkili olduğu; depresyon, anksiyete ve genel iyi oluşun ise glisemik kontrol ile ilişkili olmadığı belirlenmiştir. ${ }^{45}$ Qiu ve arkadaşlarının 1956 diyabet hastası ile yaptığı bir çalışmada hastaların \%26.8'inde ruhsal sıkıntı belirlenmiş ve ruhsal sıkıntının düşük eğitim düzeyi, boşanma/ayrılma, düşük gelir, kısa uyku süresi, hastalığın farkındalığı ve eşlik eden hastalık varlığı ile pozitif yönlü önemli bir ilişki gösterilmiştir. ${ }^{46}$

Akılcı olmayan sağlık inançları: Özellikle bazı kültürel gruplarda insülin kullanımına ilişkin akılcı olmayan sağlık inançları yaygındır. Örneğin; diyabet yaygınlığının yüksek olduğu nüfusta bireyler, kronolojik olarak insülin ile eş zamanlı ilerlemiş komplikasyonu olan aile üyelerini görerek insülin ile bu komplikasyonları ilişsilendirebilirler. Ayrıca diyabette damgalanma da yaygındır. Bazı hastalar insülin enjeksiyonu ile intravenöz ilaç kullanımının eşit sayılabileceği korkusu ile insüline başlamayı istemezler. ${ }^{2,15,28}$

\section{Diyabet Yönetiminde Ruhsal Toplumsal Girişimler}

Diyabet yönetim stratejileri, ideal olarak bireyler ve aileleri üzerinde etkili olan ruhsal toplumsal etkenleri vurgulamaktadır. ${ }^{18}$ Psikolojik sorunların yaygınlığına ve bunların olumsuz sonuçlarına rağmen birey merkezli kronik hastalık bakımı ve psikolojik destek, diyabetli 
hastalarda düşük bulunmuştur. İlgili ve şefkatli aileler, arkadaşlar, sağlık bakım profesyonelleri ve hatta diyabetli diğer hastalar aracılığıyla yapılan ruhsal toplumsal destek, diyabetli hastalarda olumlu bir bakış açısı, zorlukları yenme ve iyilik duygusu verebilir. Duygular, davranış ve fizyoloji üzerinde doğrudan bir etkiye sahiptir. Mutluluk, coşku ve memnuniyet gibi olumlu duyguların sağlık davranışlarını iyileştirdiği ve tedaviye daha iyi uyum sağlandığı gösterilmiş ${ }^{47}$ ve fiziksel aktivite gibi sağlıklı davranışın, mutluluk duygusu veren endorfin salınımına neden olduğu bunun da edimsel koşullandırma yoluyla davranışı güçlendirdiği belirtilmiştir. Olumsuz duygular ise uzun süreli enfeksiyonlara ve yara iyileşmesinin gecikmesine yol açabilmektedir. ${ }^{24}$

Diyabetli bireyler, psikolojik sıkıntı ve ruhsal bozukluklar için yapılandırılmış görüşmeler yoluyla düzenli olarak taranmalı ${ }^{48}$, yapılandırılmış eğitim programları özellikle yeni tanı alan hastalar için düzenlenmelidir. Ayrıca hastalar ruhsal sorunların tanı ve tedavisi için diyabet ruh sağlığı uzmanları tarafından ruhsal müdahaleler sunulan liyezon psikiyatri hizmetlerine yönlendirilmelidir. ${ }^{29}$ Motivasyonel girişimler, baş etme becerileri, öz etkililiği arttırma, stres yönetimi ve aile müdahalelerinin diyabet yönetiminde yardımc1 olduğu gösterilmiştir. ${ }^{49} \mathrm{Bu}$ nedenle bütün diyabetli bireyler öz bakımı kolaylaştıran bilgi, beceri ve yeteneği kazanmak ve öz yönetimi sürdürmek için gerekli davranışların uygulanması ve devam ettirilmesinde diyabet öz yönetim eğitimine katılmalıdır. ${ }^{28,50}$

Diyabet öz yönetim eğitimi ve desteği diyabet hastalarına öz yönetim kararları ve faaliyetleri izlemi için yardım etmede altyapı sağlama ve sağlık sonuçlarını iyileştirme amac1 ile yapılmaktadır. ${ }^{51}$ Diyabet öz yönetim eğitimi, diyabet öz bakımı için gerekli bilgi, beceri ve yeteneği kolaylaştıran süreçtir. Diyabet öz yönetim desteği ise öz yönetim için gerekli başa çıkma becerisi ve davranışlarını uygulamak ve sürdürmek için gerekli olan destek anlamına gelmektedir. ${ }^{6}$ Yüksek nitelikli diyabet öz yönetim eğitiminin; hastanın öz yönetimini, memnuniyetini ve glukoz sonuçlarını iyileştirdiği gösterilmiştir. ${ }^{6,51,52}$ Sağlık çalışanlarının yargılayıcı olmayan, açık iletişim biçimi ve etkili iş birliği eğitimsel, kliniksel, psikososyal ve davranışsal olmak üzere çok boyutlu diyabet bakımı hedeflerine ulaşmada çok önemlidir. ${ }^{6,28,50}$ Hastanın hekimi ile çalışan hemşirenin yürüttüğü vaka yönetimi ve kanıt temelli, hasta odaklı randomize kontrollü deneysel bir çalışmada eğitimden sonra girişim grubundaki hastaların tedaviye uyumu, bakım memnuniyeti, HbA1c, lipidler, kan basincı ve depresyon sonuçlarında iyileşme belirlenmiştir. ${ }^{48}$

Araştırmalar öz yönetim eğitimi ile birlikte psikoterapinin depresif belirtiler ve glisemik kontrol üzerinde antidepresan tedaviye göre daha büyük etkiye sahip olduğunu göstermektedir. ${ }^{53}$ Destekleyici terapi, bireyin benlik saygısını ve uyum becerilerini arttırmaya odaklanır ve kişiler arası örüntüleri araştırarak yararsız davranışları tanımlar. Motivasyonel görüşme; bireyin amaçları, değerleri ve mevcut davranışları arasındaki tutarsızlıkları belirlemesine ve değişime yönelik direnci kırmasına; psikodinamik terapi geçmişteki deneyimler yoluyla mevcut davranışı anlamaya odaklanmaktadır. Davranış terapisi ise hedef belirleme ve güçlendirme gibi teknikleri kullanır. Bir hedefe ulaşıldığı zaman veya kişi bunu yapmak için belirgin bir çaba gösterdiğinde övgü ve teşvik ile pozitif güçlendirme sağlanır. ${ }^{26,29}$ Kişiler arası terapi baş etme stratejileri ve kişiler arası ilişkiler üzerine odaklanır. Uyum bozuklukları, depresyon ve anksiyete tedavisinde en sık kullanılan terapi türü bilişsel davranışçı terapidir. Duygu, düşünce ve davranış arasındaki ilişkiyi inceler ve mevcut sorunlara yönelik çözümlere odaklanır. ${ }^{29,54}$ İşbirlikçi bir tedavi çerçevesine dayanan Optimal Sağlık Programı (OSP) ise, DM ile baş etmede öz algılama ile birlikte özdüşünüm, problem çözme ve stres yönetimi konularında psikososyal desteklerin gerekliliğini vurgulamaktadır. ${ }^{55}$ Prospektif randomize kontrollü 166 DM tanısı alan bireylerle yapılan bir çalışmada OSP'nın etkinliği değerlendirilmiştir. Psikososyal girişim grubunda olan katılımcılar, yapılandırılmış bir tedaviye dayanan dokuz $(8+1$ destekleyici oturum) ardışık oturuma katılmıştır. Katılım sonucunda OSP'nin öz yeterlik ve öz yönetim konusundaki vurgusu, katılımcılarda güçlendirme ve bağımsızlığın artırılması için bilgi ve beceri sağlayarak diyabetin fiziksel ve psikososyal karmaşıklığı ile daha etkili bir şekilde başa çıkılabildiği belirlenmiştir. ${ }^{56}$

Son yıllarda diyabet ve ruhsal sağlıkta yenilikçi bütüncül bakım modelleri, diyabet bakımının üç boyutu (3DFD) ve ekip bakım (TEAMcare) modelleri geliştirilmiştir. Bu modeller psikiyatrinin ve diyabet bakımının bütünleşmesinin yalnızca hastaların ruhsal sağlığında değil, fiziksel sağlığında da ilerleme sağlayabileceğini ortaya koymuştur. ${ }^{57,58}$

\section{SONUC}

Diyabet fizyolojik, ruhsal ve çevresel etkenler ile gelişen doğası arasındaki karmaşık etkileşimler nedeniyle zorlu bir durumdur. Diyabet komplikasyonlarının gelişme riski yetersiz glisemik kontrol ile artmaktadır. Bu nedenle hastaların kendi bakımlarında aktif rol üstlenmeleri önemlidir. Diyabetin etkili yönetiminde sağlıklı beslenme, fiziksel aktivite, tütün kullanmama, kilo yönetimi, öz yönetim sorunlarını belirleme ve stresle etkili baş etme stratejileri gibi hasta özyönetimini destekleme hedefleri, sağlık profesyonellerinin eşgüdüm içerisinde ve hasta merkezli yaklaşımı ile gerçekleştirilir. Diyabet, ruhsal sağlık ve toplumsal etkenlerin karmaşık ilişkisi bütüncül tedavi ve disiplinler arası iş birliğini geliştirme gereksinimini vurgulamaktadır. Ciddi ruhsal bozukluğu özellikle depresyonu olan hastalarda diyabet gelişme riski yüksektir. Diyabette tedavi edilmemiş ciddi ruhsal sorunlar kötü glisemik kontrol, çeşitli diyabet komplikasyonları, artan sağlık bakım maliyeti, işlevsellikte kötüleşme ve erken ölüm ile ilişkilendirilmektedir. Diyabet yönetiminin temel taşlarından olan öz bakım, diyabete eşlik eden ruhsal sorunlar nedeni ile zorlaşmaktadır. Ruhsal sorunların yaygınlığına ve bunların olumsuz sonuçlarına rağmen, diyabetli hastalarda birey merkezli kronik hastalık bakımı ve ruhsal destek yetersizdir. Bu nedenle ruhsal toplumsal bakım, işbirlikçi ve hasta merkezli yaklaşımla bütünleştirilmeli, sağlık sonuçlarını ve yaşam kalitesini en iyi duruma getirme hedefini içermelidir. En uygun tıbbi sonuçlar ve ruhsal durum iyileştirilmesinde hasta merkezli bakım esastır. Diyabet öz yönetim eğitimi ve desteği hasta merkezli, bireyin tercih, gereksinim ve değerlerine duyarlı ve saygılı, klinik kararlarda yol gösterici olmalıdır. Yüksek risk grubunda olan bireylerde diyabeti tanılama ve izlemi sürdürmede çok disiplinli 
sağlık bakım ekibinin farkındalığı ve uygulanabilir stratejileri sürdürmesi önemlidir.

\section{KAYNAKLAR}

1. Conti C, Mennitto C, Di Francesco G, Fraticelli $\underline{F}$, Vitacolonna E, Fulcheri Clinical characteristics of diabetes mellitus and suicide risk. Front Psychiatry 2017; 8: 1-7.

2. Doherty AM. Psychiatric aspects of diabetes mellitus. BJ Psych Advances 2015; 21,407-416.

3. American Diabetes Association. Standards of medical care in diabetes-2017. Introduction. Ed: Cefalu WT. Diabetes Care. The Journal of Clinical and Applied Research and Education 40 (Suppl. 1):s1-s2.

4. IDF Diabetes Atlas. http://www.diabetesatlas.org/resources/2017atlas.html. Erișim: 26.07.2017.

5. Türkiye Diyabet Programı 2015-2020. Türkiye'de diyabetin mevcut durumu. http://diyabet.gov.tr/content/files/guncel/turkiye_diy abet programi.pdf. Erișim: 26.07.2017.

6. Powers MA, Bardsley J, Cypress M, Duker $\underline{\text { P, Funnell MM}, ~ F i s c h l ~ A H}$, et al. Diabetes SelfManagement Education and Support in Type 2 Diabetes: A Joint Position Statement of the American Diabetes Association, the American Association of Diabetes Educators, and the Academy of Nutrition and Dietetics. Clin Diabetes. 2016 ;34: 70-80.

7. American Diabetes Association. Standards of medical care in diabetes-2017. Promoting health and reducing disparities in populations. Ed: William $\mathrm{T}$. Cefalu. Diabetes Care The Journal of Clinical and Applied Research and Education 2017;40 (Suppl. 1):s6-s10.

8. The TRIAD Study Group. Health systems, patients factors, and quality of care for diabetes: a synthesis of findings from the TRIAD study. Diabetes Care 2010; 33: 940-947.

9. O'Connor PJ, Bodkin NL, Fradkin J, Glasgow RE, Greenfield S, Gregg E, et al. Diabetes performance measures: current status and future directions. Diabetes Care 2011; 34:1651-9.

10. Davidson MB. How our current medical care system fails people with diabetes: lack of timely, appropriate clinical decisions. Diabetes Care 2009; 32: 370-372.

11. Jack L, Jack NH, Hayes SC. Social determinants of health in minority populations: a call for multidisciplinary approaches to eliminate diabetesrelated health disparities. Diabetes Spectr 2012;25:9-13.

12. Ricci-Cabello I, Ruiz-P'erez I, Olry de Labry- Lima A, M'arquez-Calder'on S. Do social inequalities exist in terms of the prevention, diagnosis, treatment, control and monitoring of diabetes? A systematic review. Health Soc Care Community 2010;18:572-587.

13. Hill JO, Galloway JM, Goley A, et al. Scientific statement: socioecological determinants of evidence? Nat. Rev. Endocrinol. 2014; 10, 258-260.
14. Mozaffarian D, Hao T, Rimm EB, Willett WC, Hu FB. Changes in diet and lifestyle and long-term weight gain in women and men. $\mathrm{N}$ Engl $\mathrm{J}$ Med 2011;364:2392- 2404.

15. American Diabetes Association. Standards of medical care in diabetes-2017. Comprehensive medical evluation and assessment of comorbidities. Ed: Cefalu WT. Diabetes Care. The Journal of Clinical and Applied Research and Education 40(Suppl. 1):s25-s32.

16. Cohn T. Schizophrenia and diabetes. Current Psychiatry 2012; 10: 29-46.

17. Lee SWH, Ng KY, Chin WK. The impact of sleep amount and sleep quality on glycemic control in type 2 diabetes: a systematic review and metaanalysis. Sleep Med Rev 2016;S10870792(16)00017-4.

18. Robinson DJ, Luthra M, Vallis M. Diabetes and mental health. Canadian Diabetes Association Clinical Practice Guidelines Expert Committee Can J Diabetes 2013; 37; S87-S92.

19. Brown ES, Varghese FP, McEwen BS. Association of depression with medical illness: does cortisol play a role? Biol Psychiatry. 2004; 1;55(1):1-9.

20. Rawlings AM, Sharrett AR, Schneider AL, Coresh $\mathrm{J}$, Albert M, Couper D, et al. Diabetes in midlife and cognitive change over 20 years: a cohort study. Ann Intern Med 2014; 161:785-93.

21. Strachan MW, Price JF. Diabetes. Cognitive decline and T2DM-a disconnect in the evidence? Nat Rev Endocrinol 2014; 10:258-60.

22. Gudala K, Bansal D, Schifano F, Bhansali A. Diabetes mellitus and risk of dementia: a meta analysis of prospective observational studies. J Diabetes Investig 2013; 4: 640-650.

23. Katon W, Pedersen HS, Ribe AR, Fenger-Grøn M, Davydow D, Waldorff FB, et al. Effect of depression and diabetes mellitus on the risk for dementia: a national population-based cohort study. JAMA Psychiatry 2015; 72: 612-9.

24. Chew BH, Ghazali SS, Fernandez A. Psychological aspects of diabetes care: Effecting behavioral change in patients. World J Diabetes 2014; 5: 796808 .

25. Siddiqui S. Depression in type 2 diabetes mellitus--a brief review. Diabetes Metab Syndr. 2014; 8: 62-5.

26. Öztürk MO, Uluşahin A. Ruh Sağlığ1 ve Bozuklukları. 14. Bask1. Miki Matbaacılık, Nobel Tip Kitabevleri, Ankara, 2016; s: 556-561.

27. Chaudhry R, Mishra P, Mishra J, Parminder $\mathrm{S}$, Mishra BP.Psychiatric morbidity among diabetic patients: A hospital-based study. Ind Psychiatry J 2010; 19: 47-49.

28. Young-Hyman D, Groot $M$ de, Hill-Briggs F, Gonzalez JS, Hood K, Peyrot M. Psychosocial care for people with diabetes: a position statement of the American Diabetes Association. Diabetes Care 2016; 39: 2126-2140.

29. Britneff E, Winkley K. The role of psychological interventions for people with diabetes and mental health issues. J Diabetes Nurs 2013; 17:305-310.

30. Roy T, Lloyd CE, Parvin M, Mohiuddin KGB, Rahman M. Prevalence of co-morbid depression in out-patients with type 2 diabetes mellitus in Bangladesh. BMC Psychiatry 2012; 12: $1-10$. 
31. Löfman S, Hakko H, Mainio A, Timonen M, Räsänen P. Characteristics of suicide among diabetes patients: a population based study of suicide victims in Northern Finland. J Psychosom Res 2012; 73: 268-71.

32. Handley TE, Ventura AD, Browne JL, Rich J, Attia $\underline{\text { JR, Reddy } \mathrm{P}}$ et al. Suicidal ideation reported by adults with Type 1 or Type 2 diabetes: results from Diabetes MILES-Australia. Diabet Med 2015; 33 : 1582-1589.

33. Avci D, Çetinkaya A, Karahan S, Oğuzhan $\underline{N}$, Karagöz H, Başak M, et al. Suicide commitment with metformin: our experience with five cases. Ren Fail 2013; 35: 863-5.

34. Bener A, Al-Hamaq AOAA, Dafeeah EE. High Prevalence of Depression, Anxiety and Stress Symptoms Among Diabetes Mellitus Patients. Open Psychiatr J 2011; 5: 5-12.

35. Sönmez B, Kasım İ. Diabetes mellitus'lu hastaların anksiyete, depresyon durumları ve yaşam kalitesi düzeyleri. Türk Aile Hek Derg 2013; 17:119-124.

36. Young V, Eiser C, Johnson B, Brierley S, Epton $\mathrm{T}$, Elliott $\mathrm{J}$, et al. Eating problems in adolescents with Type 1 diabetes: a systematic review with meta-analysis. Diabet Med. 2013; 30: 189-98.

37. Garret C, Doherty A. Diabetes and mental health. Clinical Medicine 2014; 14: 669-72.

38. Dalvi M, Feher M, Caglar E, Catalan J. Liaison psychiatrist in a specialist diabetes centre. Psychiatr Bull 2008; 32: 461-463.

39. Holt RI, Mitchell AJ. Diabetes mellitus and severe mental

illness: mechanisms and clinical implications. Nat Rev Endocrinol 2015; 11: 79-89.

40. Sarısoy G, Böke Ö, Öztürk A, Akkaya D, Pazvantoğlu O, Şahin AR. Şizofreni hastalarında metabolik sendrom siklığının sosyodemografik ve klinik özelliklerle ilişkisi. Düşünen Adam The Journal of Psychiatry and Neurological Sciences 2013; 26: 267-275.

41. Allison DB, Mentore JL, Heo M, Chandler LP, Cappelleri JC, Infante MC, et al. Antipsychoticinduced weight gain: a comprehensive research synthesis. Am J Psychiatry 1999; 156: 1686-96.

42. Le Noury J, Khan A, Harris M, Wong W, Williams $\mathrm{D}$, Roberts $\mathrm{T}$, et al. The incidence and prevalence of diabetes in patients with serious mental illness in North West Wales: two cohorts, 1875-1924 \& 1994-2006 compared. BMC Psychiatry 2008; 8: 18.

43. Nash J. Dealing with diagnosis of diabetes. Practical Diabetes 2015; 32: 19-23.

44. Bootle S, Skovlund SE. Proceedings of the 5th International DAWN Summit 2014: Acting together to make personcentred diabetes care a reality. Diabetes Res Clin Pract 2015; 109:6-18.

45. Strandberg RB, Graue M, Wentzel-Larsen T, Peyrot $\underline{\mathrm{M}}$, Rokne B. Relationships of diabetes-specific emotional distress, depression, anxiety, and overall wellbeing with $\mathrm{HbA} 1 \mathrm{c}$ in adult persons with type 1 diabetes. J Psychosom Res 2014; 77: 174-9.

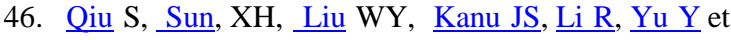
al. Prevalence and correlates of psychological distress among diabetes mellitus adults in the Jilin province in China: a cross-sectional study. Peer J 5: e2869.1-17

47. Pressman SD, Cohen S. Does positive affect influence health? Psychol Bull 2005; 131: 925-71.

48. Katon WJ, Lin EHB, Von Korff M, Ciechanowski

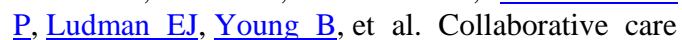
for patients with depression and chronic illnesses. $\mathrm{N}$ Engl J Med 2010; 363:2611-20.

49. Osborn CY, Egede LE. Validation of an Information-Motivation-Behavioral Skills model of diabetes self-care (IMB-DSC). Patient Educ Couns 2010; 79: 49-54.

50. American Diabetes Association. Standards of medical care in diabetes-2017. Lifestyle management. Ed: William T. Cefalu. Diabetes Care The Journal of Clinical and Applied Research and Education 40(Suppl. 1):s33-s43.

51. Brunisholz KD, Briot $\mathrm{P}$, Hamilton $\mathrm{S}$, Joy EA, Lomax M, Barton N, et al. Diabetes selfmanagement education improves quality of care and clinical outcomes determined by a diabetes bundle measure. J Multidiscip Healthc 2014; 7:533-542.

52. Hill JO, Galloway JM, Goley A, Marrero $\underline{\mathrm{DG}}, \underline{\text { Minners R}}, \underline{\text { Montgomery B }}$ et al. Scientific statement: socioecological determinants of prediabetes and type 2 diabetes. Diabetes Care 2013; 36: $2430-9$

53. van der Feltz-Cornelis CM, Nuyen J, Stoop C, Chan J, Jacobson AM, Katon W, et al. Effect of interventions for major depressive disorder and significant depressive symptoms in patients with diabetes mellitus: a systematic review and metaanalysis. Gen Hosp Psychiatry 2010; 32: 380-95.

54. Beck AT, Rush AJ, Shaw BF, Emery G. Cognitive Therapy of Depression. New York: Guilford Press, 1979.

55. Gilbert MM, Chamberlain JA, White CR. Mayers PW, Pawsey B, Liew $\quad$ D, et al. Controlled clinical trial of a self management program for people with mental illness in an adult mental health service the Optimal Health Program (OHP). Aust Health Rev 2012; 36:1-7.

56. O'Brien CL, Ski CF, Thompson DR, Moore G, Mancuso S, Jenkins A, et al. The Mental Health in Diabetes Service (MINDS) to enhance psychosocial health: study protocol for a randomized controlled trial. Trials 2016; 17: 444. 1-10.

57. Archer $\mathrm{N}$, Ismail $\mathrm{K}$, Bridgen $\mathrm{O}$, Morgan-Jone $\mathrm{K}$, Pryce L, Gayle C. Three dimensions of care for diabetes: a pilot service. J Diabetes Nurs 2012; 16: 123.

58. Doherty AM, Gayle C, Morgan-Jones R, Archer $\underline{\mathrm{N}}$, Laura-Lee, Ismail $\frac{\mathrm{K}}{\mathrm{N}}$, et $\frac{\text { al. }}{\text {. }}$ Improving quality of diabetes care by integrating ps ychological and social care for poorlycontrolled diab etes: 3 Dimensions of Care for Diabetes. Int J Psychiatry Med. 2016;51:3-15. 